\title{
Using digital platforms for environmental management
}

\author{
Anna Balabanova ${ }^{1, *}$, Nadezhda Keschyan $^{1}$, Tatyana Borisova ${ }^{1}$, and Ekaterina \\ Hachemizova $^{1}$ \\ ${ }^{1}$ Sochi State University, 354000, Ulitsa Plastunskaya, 94, Sochi, Russia
}

\begin{abstract}
The article discusses the possibility of using digital platforms for environmental management. The aim of the research is to determine the directions of using digital platforms for environmental management. To preserve the environment, increase energy conservation and sustainable development of territories, effective management is always important. Digital innovation allows citizens to engage, develop environmental volunteering, improve environmental literacy, collect more environmental data, and improve governance. The work identified the types of digital platforms depending on the subject of management, the main types of digital platforms and the main type of activity based on the chosen platform. The article considered the main digital platforms for environmental management in the field of ecology and the environment of the Russian Federation, highlighted the main functions of the platforms, problems and development directions. It is necessary to create such hybrid systems of environmental supervision in the field of water resources protection, to detect the facts of illegal construction and violation of construction parameters, remote control over the intended use of land, deforestation, and the environmental situation in water and air.
\end{abstract}

\section{Introduction}

To preserve the environment, improve energy conservation and sustainable development of territories, effective management is always important. Modern technologies for improving processes and control systems can reduce costs and create new opportunities, tools and services.

One of these modern areas of digital solutions is digital platforms.

More and more researchers are paying attention to the possibilities of introducing digital platforms for environmental management, involving citizens and volunteers in environmental activities.

Digital innovation allows citizens to engage, develop environmental volunteering, improve environmental literacy, collect more environmental data, and improve project coordination. [1-3]

Separate researches have revealed both positive and negative impact of the development of digital technologies on the environment. [4-5]

\footnotetext{
*Corresponding author: annabalabanovasochi@gmail.com
} 
Some researchers pay attention to the problems that need to be overcome when developing an intelligent educational environment, taking into account the main characteristics and individual support of the environment. They explore the integration of intelligent learning environments, innovative applications and new teaching methods to coordinate formal and non-formal learning in ecology and the environment. Deep learning is one of the modern techniques that can be used to automate the process of efficient intelligent learning based on image detection. [6]

Special attention should be paid to state digital platforms. Thus, public administration is one of the main management systems in the field of the environment. [7]

Digital platforms have been effectively used for years in various areas of environmental management.

Digital platforms are proposed to be used for digital energy management. To do this, researchers develop architecture models for a coherent and interoperable platform. [8]

Researchers are exploring digital platforms for collecting forestry information. The most active platform users in Finland are forest owners who produce timber.

Such services make forestry services independent of time and place, make it easier to obtain the service, and make it more attractive. [9]

Another important area for environmental management is to improve the efficiency of logistics. Sustainable green supplies are influenced by digital transformation technologies. Researchers highlight the prospects for introducing digital transformation technologies for more sustainable processes in logistics and supply chain management of manufacturing companies. Digital platforms drive improvements in energy efficiency, shorten transport and distribution distances and optimize logistics resources, and improve social and environmental sustainability. Research results confirm that the use of digital technologies in logistics and supply chain management has a moderate positive impact on aspects of environmental and social sustainability. [10]

We also highlight another area of environmental management - the use of digital platforms for the sharing economy. Co-economy platforms have a set of necessary exchange intermediation capabilities. [11]

Digital platforms are also helping to combat food waste. Digital platforms are becoming key factors in successful food exchange. [12-13]

\section{Materials and Methods}

For the research, analytical, statistical, comparative methods, the grouping method were used, an analysis of digital platforms in the field of ecology and the environment in the Russian Federation was carried out. The results of social research in the field of ecology and the environment, statistical data of state and municipal authorities, statistical organizations were used as an information base.

The aim of the study is to determine the directions of using digital platforms for environmental management.

The article describes the collected database for empirical analysis. The database on digital platforms in the field of ecology and the environment in the Russian Federation is also described, and the landscape of Russian platforms is described. Next, some examples of platforms included in the data are discussed that may represent their activities. Platforms and other variables collected for analysis are also compared.

\section{Results}


Digital platforms are becoming the norm for society and are used in more and more economic processes. There are more and more participants in digital platforms. Since every year the percentage of the world's inhabitants who have access to the Internet increases, the cost of using the Internet decreases, as well as increasing geographic accessibility. The number of gadgets and devices with Internet access is increasing. All this makes digital platforms more accessible.

The analysis has shown that existing digital platforms in the field of ecology provide users with a simplified way to work with complex intellectual functions, and a wide range of new opportunities, solutions and tools.

Let's highlight the types of digital platforms depending on the subject of management:

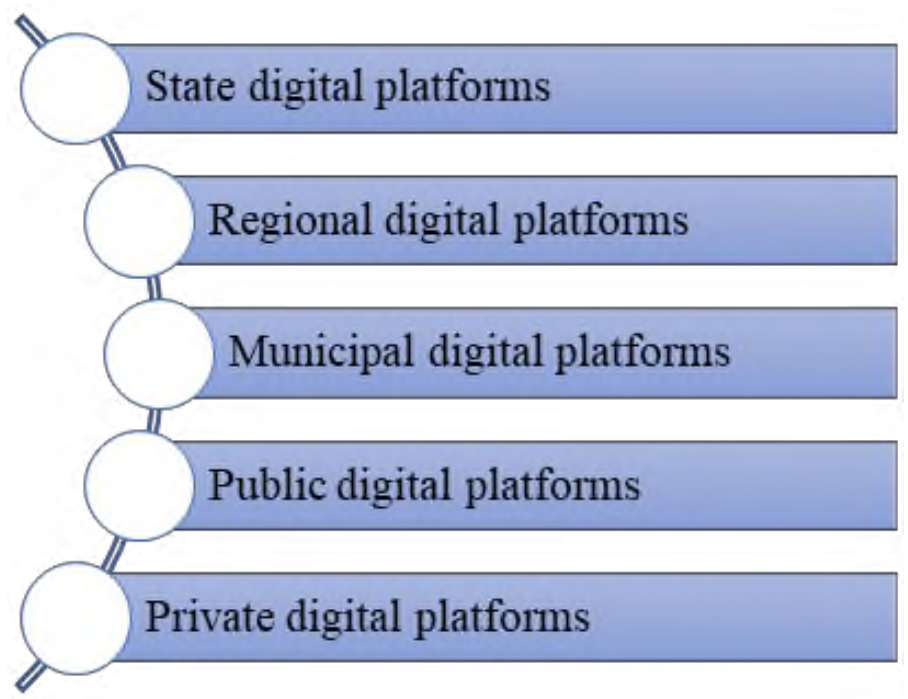

Fig. 1. Types of digital platforms depending on the subject of management

Let's highlight the main types of digital platforms:

Table 1. Main types of digital platforms.

\begin{tabular}{|l|l|l|}
\hline № & Types of digital platform & Main type of activity based on the platform \\
\hline 1. & Instrumental digital platform & $\begin{array}{l}\text { Development of software } \\
\text { and software and hardware solutions }\end{array}$ \\
\hline 2. & Infrastructure digital platform & $\begin{array}{l}\text { IT service delivery } \\
\text { and information for decision making }\end{array}$ \\
\hline 3. & Applied digital platform & $\begin{array}{l}\text { Exchange of certain economic } \\
\text { values in specified markets }\end{array}$ \\
\hline
\end{tabular}

Instrumental digital platform. It is based on a software or hardware-software complex (product) designed to create software or hardware-software solutions for applied purposes.

Infrastructure digital platform. It is based on an ecosystem of informatization market participants, the purpose of which is to accelerate the introduction to the market and provide consumers in economic sectors with solutions for the automation of their activities (IT services), using end-to-end digital technologies for working with data and access to data sources, implemented in the infrastructure of this ecosystem.

Applied digital platform. A business model for providing the possibility of an algorithmic exchange of certain values between a significant number of independent market participants by conducting transactions in a single information environment, leading to a 
decrease in transaction costs due to the use of digital technologies and changes in the division of labor.

Table 2. Digital platforms for environmental management in the field of ecology and the environment of Russia

\begin{tabular}{|c|c|c|c|}
\hline № & Name & Address & $\begin{array}{l}\text { Website } \\
15.01 .2021-15.02 .2021\end{array}$ \\
\hline 1. & $\begin{array}{l}\text { Federal and } \\
\text { government services }\end{array}$ & https://www.gosuslugi.ru & 76680000 visitors \\
\hline 2. & Regional government services & https://pgu.krasnodar.ru/ & 74700 visitors \\
\hline 3. & Federal State Statistics Service & http://old.gks.ru/ & 32600 visitors \\
\hline 4. & Government purchase portal & https://zakupki.gov.ru/ & 3810000 visitors \\
\hline 5. & $\begin{array}{l}\text { Ministry of Natural Resources and } \\
\text { Environment of the Russian } \\
\text { Federation }\end{array}$ & https://www.mnr.gov.ru/ & 77500 visitors \\
\hline 6. & $\begin{array}{l}\text { Ministry of Natural Resources of } \\
\text { the Krasnodar Region }\end{array}$ & http://mprkk.ru/ & 10200 visitors \\
\hline 7. & Roshydromet & http://www.meteorf.ru/ & 137000 visitors \\
\hline 8. & $\begin{array}{l}\text { Federal and regional geoportals of } \\
\text { Russia }\end{array}$ & $\begin{array}{l}\text { http://gisgeo.org/gisporta } \\
\text { 1/geoportals.html\#mgis }\end{array}$ & 3260 visitors \\
\hline 9. & $\begin{array}{l}\text { "Unified state platform for data } \\
\text { collection of the industrial Internet } \\
\text { of things" }\end{array}$ & Закрытый доступ & - \\
\hline 10. & $\begin{array}{l}\text { nteractive electronic map of } \\
\text { subsoil use of the Russian } \\
\text { Federation }\end{array}$ & $\begin{array}{l}\text { https://openmap.mineral. } \\
\mathrm{ru/}\end{array}$ & 6910 visitors \\
\hline 11. & $\begin{array}{l}\text { Remote Monitoring Information } \\
\text { System }\end{array}$ & https://nffc.aviales.ru/ & 37752 visitors \\
\hline 12. & $\begin{array}{llll}\begin{array}{l}\text { Interactive map } \\
\text { Russia" }\end{array} & & & \end{array}$ & $\begin{array}{l}\text { http://geo.roslesinforg.ru } \\
: 8282 / \# /\end{array}$ & 46554 visitors \\
\hline 13. & $\begin{array}{l}\text { Regional Geographic Information } \\
\text { System of the Moscow Region } \\
\text { (RGIS MR) }\end{array}$ & https://www.mogt.ru/ & 2850 visitors \\
\hline 14. & Geoportal of Modmoskovye & https://rgis.mosreg.ru/ & 66100 visitors \\
\hline 15. & $\begin{array}{l}\text { System of ecological monitoring } \\
\text { of the environment SEME }\end{array}$ & Closed access & - \\
\hline 16. & $\begin{array}{ll}\begin{array}{l}\text { Environmental } \\
\text { platform "MegaFon" }\end{array} & \text { monitoring } \\
\end{array}$ & Closed access & - \\
\hline 17. & Russian environmental operator & https://radar.reo.ru/ & 5380 visitors \\
\hline 18. & Russian Ecological Society & $\begin{array}{l}\text { https://www.ecosociety.r } \\
\mathrm{u} /\end{array}$ & 2500 visitors \\
\hline 19. & 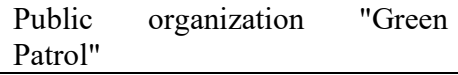 & https://greenpatrol.ru/ru & 9870 visitors \\
\hline 20. & Map of socio-ecological conflicts & $\begin{array}{l}\text { https://map.ecosociety.ru } \\
/\end{array}$ & 15345 visitors \\
\hline
\end{tabular}

State and municipal management is one of the most important elements in the environmental management system.

The use of online technology means the presence of government agencies and agencies on the Internet. A special place is occupied by the provision of state and municipal digital services.

State and municipal web portals, sites, services in the conditions of modern reality are becoming key factors. [14] 
Consider one of the most important areas of government services - "Federal and municipal government services." This digital portal allows you to quickly and at the lowest cost, a large number of federal, regional government services, as well as relevant municipal services. Also, the service allows you to reduce the cost and time of rendering services, improve their quality.

The website of the Federal State Statistics Service allows you to obtain statistical data on the real state of ecology, the environment, as well as order analytical reports.

Consider one major state digital platform - "Unified information system in the field of procurement" and more than 10 electronic platforms that allow customers to organize electronic procurement procedures, and potential suppliers to participate in them, competing for the right to supply products to this customer. These sites make it possible to increase the turnover of the ecological market, competitiveness, safety, achieve budget savings, reduce prices for environmentally friendly goods, and also identify violators.

In this service, a separate direction is acquired by the organization of "green" procurement - this is the procurement of goods and services that are subject to environmental requirements. Compliance with these requirements is considered along with the price when choosing a supplier. In this way, the state can support responsible producers and protect the environment.

In 2018, the total volume of government purchases in Russia amounted to RUB 21 trillion. This means that this instrument can be an important mechanism for economic and environmental policy.

The websites of federal ministries and their structural subdivisions in the field of ecology, for example, the Ministry of Natural Resources and Ecology of the Russian Federation, perform the main functions:

- informational,

- legal,

- organization of communication with citizens,

- organization of social monitoring,

- methodical.

At the regional level, one can cite as an example the website of the Ministry of Natural Resources of the Krasnodar Region.

Let's consider the ROSHYDROMET platform separately. The platform provides a wide range of products and services for hydrometeorology, environmental, weather and climate monitoring, as well as licensing and control. [15, 2020, 16, 2019]

Federal authorities have developed more than 20 geographic information systems and more than 50 regional ones. These portals contain a wide variety of services. Among them: "Interactive electronic map of the subsoil use of the Russian Federation", "Information system for remote monitoring", "Interactive map" Forests of Russia ".

In 2020, the "Unified State Platform for Data Collection of the Industrial Internet of Things" was launched. This is a system that is used as a cloud solution by regulatory authorities for remote control, analysis of streaming and structured data, and risk prediction. The project budget was $237,500,000$ rubles.

This digital platform uses the Internet of Things (IoT) technology and is included in the government performance platform. The platform is based on the Mail.ru IoT Platform Internet of Things technology, which provides collection, processing and storage of data. This solution is actively aimed at monitoring pollution and forest accounting.

A successful regional digital platform that can be used for environmental management is the Regional Geographic Information System of the Moscow Region (RGIS MO). On an interactive map in electronic form in real time, you can get all the information about the forests. Information about all activities carried out by the forestry department of the region, from the sites where sanitary felling is carried out, to the coordinates of the sites where 
seedlings with a closed root system are planted, is also promptly posted there. Thanks to the portal, it is possible to monitor the execution of forestry works, in addition, digitization made it possible to identify all land plots, the boundaries of which cross the lands of the forest fund.

System of ecological monitoring of the environment SEMOS. The system of environmental monitoring of the environment "SEMOS" performs continuous, round-theclock, automated monitoring of the state of the environment and ensures timely provision of responsible persons with reliable information for making effective management decisions in the field of environmental protection and pollution monitoring.

The environmental monitoring platform automates the collection of data on the state of the environment, conducts centralized processing and analysis of this data in order to promptly respond to environmental incidents and further make effective management decisions.

Business is also actively developing digital platforms, using them as commercial business models.

MegaFon has developed a system for monitoring the environmental situation in automatic mode, which includes a set of sensors connected by a local network with control servers, workstations of specialists and control posts of the relevant services. This solution was implemented on the basis of a proprietary data collection platform for the Industrial Internet of Things.

MegaFon's digital product enables the management of industrial enterprises to control air emissions at their facilities in order to implement the requirements of the current legislation.

This platform will be able to provide the state authorities of the constituent entities of the Russian Federation with information reflecting in real time the quality of atmospheric air in settlements. In addition, the eco-monitoring platform can also be used as a solution for controlling the microclimate of indoor spaces, ensuring compliance with sanitary and epidemiological rules and regulations.

The features of the new platform from "MegaFon" include various options for visualizing the collected data, prompt display of contextual information, arming potentially dangerous objects. Additionally, the platform allows you to receive and accumulate video streams from surveillance cameras, notify responsible specialists and solve a number of other tasks. All this makes it possible to timely identify environmental incidents, prevent emergency situations, promptly respond to changes in the quality of environmental components and, as a result, minimize the costs of eliminating the consequences.

The Russian environmental operator offers solutions in the field of waste disposal, as well as receiving active feedback from citizens.

Digital platforms of public organizations, which are primarily social in nature, can be distinguished into a separate category. For example, the Russian Ecological Society and the Green Patrol public organization offer information services, educational platforms in the field of environmental literacy, and an interactive map of socio-ecological conflicts.

Hybrid eco-monitoring is one of the most effective indicators of the environmental situation. It allows you to collect information about the degree of well-being with a gradation. To link the state of the measurement object with the degree of pollution of the atmosphere, water resources and geological environment, objectively inform about the environmental situation in general. The map of the state of the research object, automatically created on the basis of these data, is actually a synthetic ecological map of the city.

The system will be able to simultaneously collect and process data from sensors on Earth and information received from spacecraft for remote sensing of the Earth (D33).

Such a hybrid system is effectively used in the field of land monitoring. 


\section{Discussion}

What are the prospects for using digital platforms in environmental management and how much are they in demand? The results of the analysis showed that digital platforms in the environmental management system of the territory of Russia are being used more and more actively every year. In their activities, this technology is used not only by state and municipal authorities, but also by public organizations and business.

In recent years, funding for projects to create digital platforms in the field of ecology and nature management has only increased, the range of products, services and technologies used in such platforms is expanding.

The results of the research showed that these solutions allow the control and supervisory authorities to abandon massive and expensive inspections for the budget, reduce the number of inspectors, reduce corruption risks, reduce damage to legally protected values through the use of automatic systems for responding to the emergence of a hazard, and also reduce administrative the burden on the audited persons. The platforms also make environmental education more accessible, open an information resource for companies, services and products in the field of environmental management and ecology.

\section{Conclusions}

The digital platforms available cover almost the entire potential and range of possible functions. State platforms are mainly represented among digital platforms in the field of environment and ecology. Platforms should offer more balanced information and more services and facilities. Large digital platforms can mainly be afforded by government authorities or large organizations. In the system of digital platforms, big data and Internet of things technologies are actively used. The most promising area is the combination of platforms and technologies, for example, hybrid eco-monitoring.

It is necessary to create such hybrid systems of environmental supervision in the field of water resources protection, to detect the facts of illegal construction and violation of construction parameters, remote control over the intended use of land, deforestation, and the environmental situation in water and air. It is also possible in the future to use these systems in solutions for monitoring the state of housing and communal services, monitoring of hazardous facilities and engineering structures.

Digital platforms provide a single information space for the interaction of all controlling and executing agencies, accelerate the solution of environmental problems, operation and development of such facilities. The complex of technologies will allow you to regularly receive up-to-date data on the state of remote or extended objects, for example, nature reserves, rivers, highways of federal and regional significance. Now monitoring such objects is difficult, however, technologies such as the Internet of Things can help in solving this problem.

\section{References}

1. K. Arts, Y. Melero, R. Wal, Journal of Environmental Management 8 April., 110497 (2020)

2. Y. L. Jing, D. L. Cuic, International Journal of Production Economics, 229, 107777 (2020)

3. A. I. Leonow, M. N. Koniagina, S. V. Petrova, S. Y. Kerimkhulle, V. G. Shubaeva, Espacios, 40(38) (2019) 
4. V. Kostakisac, A. Roosbc, M. Bauwensd, Environmental Innovation and Societal Transitions, 18, 82-100 (2016)

5. M. Egorova, O. Garanina, S. Petrova, I. Okhrimenko, El papel del capital social en la formación de una comunidad sostenible. Opcion, 35, 1446-1474 (2019)

6. Z. H. A. Xu, Microprocessors and Microsystems, 80, 103343 (2021)

7. P. Henmana, T. Graham, Government Information Quarterly, 37(2) (2020)

8. P. P. Senna, A. H. Almeida, A. L. Azevedo, Procedia Manufacturing, 1117-1124 (2020)

9. S. Pynnönena, E. Haltiabd, T. Hujala, Forest Policy and Economics, 125, 102404 (2021)

10. A. L. Jungea, F. Straube, Procedia Manufacturing, 43, 736-742 (2020)

11. W. Sutherland, M. H. Jarrahi. International Journal of Information Management, 43, December, 328-341 (2018)

12. Q. C. Aouina-Mejrie, A. Mazzucchellia, M. Guriolib, D. Grazianoc, Journal of Business Research, 124, 47-58 (2021)

13. Sh. Mullick, N. Raassens, H. Haans, E. J.Nijssen, Industrial Marketing Management (2020)

14. N. Duch-Browna, F. Rossetti, Energy Policy, 144, 111612 (2020)

15. A. Balabanova, N. Keschyan, T. Borisova, E. Hachemizova, E3S Web of Conferences, 91, 08019 (2019) 